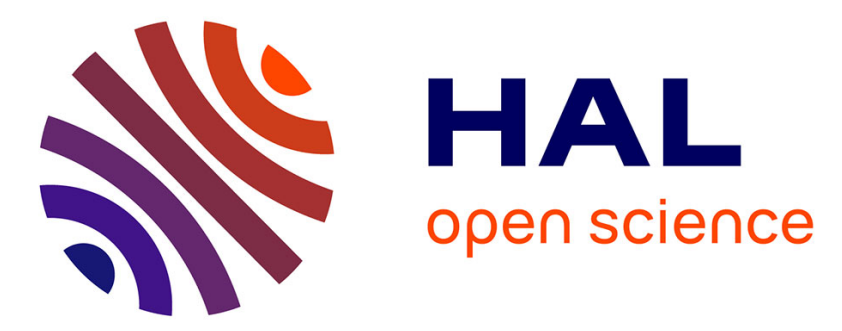

\title{
Atmospheric loss of nitrous oxide (N2O) is not influenced by its potential reactions with $\mathrm{OH}$ and $\mathrm{NO} 3$ radicals
}

A R Ravishankara, Anne-Laure Pelé, Li Zhou, Yangang Ren, Antonia Zogka, Véronique Daële, Mahmoud S Idir, Steven P.Brown, Manolis N. Romanias, Abdelwahid S Mellouki

\section{To cite this version:}

A R Ravishankara, Anne-Laure Pelé, Li Zhou, Yangang Ren, Antonia Zogka, et al.. Atmospheric loss of nitrous oxide $(\mathrm{N} 2 \mathrm{O})$ is not influenced by its potential reactions with $\mathrm{OH}$ and $\mathrm{NO} 3$ radicals. Physical Chemistry Chemical Physics, 2019, 44, 10.1039/C9CP04818A . insu-02373036

\section{HAL Id: insu-02373036 \\ https://hal-insu.archives-ouvertes.fr/insu-02373036}

Submitted on 20 Nov 2019

HAL is a multi-disciplinary open access archive for the deposit and dissemination of scientific research documents, whether they are published or not. The documents may come from teaching and research institutions in France or abroad, or from public or private research centers.
L'archive ouverte pluridisciplinaire HAL, est destinée au dépôt et à la diffusion de documents scientifiques de niveau recherche, publiés ou non, émanant des établissements d'enseignement et de recherche français ou étrangers, des laboratoires publics ou privés.

\section{(1) (1) $\$$}

Distributed under a Creative Commons Attribution - NonCommercial - NoDerivatives| 4.0 


\section{Atmospheric loss of nitrous oxide $\left(\mathrm{N}_{2} \mathrm{O}\right)$ is not influenced by its potential reactions with $\mathrm{OH}$ and $\mathrm{NO}_{3}$ radicals}

A.R. Ravishankara, ${ }^{* a, b, c}$ Anne-Laure Pele, ${ }^{\mathrm{a}}$ Li Zhou, ${ }^{\mathrm{a}, \mathrm{d}}$ Yangang Ren, ${ }^{\mathrm{a}}$ Antonia Zogka, ${ }^{\mathrm{a}}$ Véronique Daële, ${ }^{\mathrm{a}}$ Mahmoud Idir, ${ }^{\mathrm{a}}$ Steven S. Brown, ${ }^{\mathrm{e}, \mathrm{f}}$ Manolis N. Romanias, ${ }^{\mathrm{g}}$ and Abdelwahid Mellouki. ${ }^{* a}$

a. Institut de Combustion, Aérothermique, Réactivité et Environnement/OSUC, CNRS, 45071 Orléans Cedex 02, France.

b. Departments of Chemistry and Atmospheric Science, Colorado State University, Fort Collins, CO 80253, USA.

c. Le Studium Loire Valley Institute for Advanced Studies, Orléans, France.

d. Current Address: College of Architecture and Environment, Sichuan University, 610065 Chengdu, China.

e. National Oceanic and Atmospheric Administration, Earth System Research Laboratory, Chemical Sciences Division, 325 Broadway, Boulder, CO 80305, USA.

f. Department of Chemistry, University of Colorado, Boulder, CO 80309, USA.

g. IMT Lille Douai, Univ. Lille, SAGE 59000 Lille, France.

*Address correspondence to:

A.R.Ravishankara@colostate.edu or mellouki@cnrs-orleans.fr 


\section{Abstract}

The rate coefficient for the possible reaction of $\mathrm{OH}$ radical with $\mathrm{N}_{2} \mathrm{O}$ was determined to be $\mathrm{k}_{1}<1 \times 10^{-17} \mathrm{~cm}^{3}$ molecule $\mathrm{e}^{-1} \mathrm{~s}^{-1}$ between 253 and $372 \mathrm{~K}$ using pulsed laser photolysis to generate $\mathrm{OH}$ radicals and pulsed laser induced fluorescence to detect them. The rate coefficient for the reaction of $\mathrm{NO}_{3}$ radical with $\mathrm{N}_{2} \mathrm{O}$ was measured to be $\mathrm{k}_{2}<5 \times 10^{-20} \mathrm{~cm}^{3}$ molecule $\mathrm{s}^{-1} \mathrm{~s}^{-1}$ at $298 \mathrm{~K}$ using a direct method that involves a larger reaction chamber equipped with cavity ring down spectroscopic detection of $\mathrm{NO}_{3}$ and $\mathrm{N}_{2} \mathrm{O}_{5}$. Various tests were carried out ensure the accuracy of our measurements. Based on our measured upper limits, we suggest that these two reactions alter the atmospheric lifetime of $\mathrm{N}_{2} \mathrm{O}$ of $\sim 120$ years by less than $4 \%$.

\section{Introduction}

Nitrous oxide, $\mathrm{N}_{2} \mathrm{O}$, is the third most important greenhouse gas ${ }^{1}$ and is now the most important emission of an ozone layer depleting gas. ${ }^{2}$ Nitrous oxide has both natural and anthropogenic sources. ${ }^{3}$ All $\mathrm{N}_{2} \mathrm{O}$ sources are spatially diffuse and emission rates from individual sources are low; therefore, it is difficult to quantify the emissions from individual sources. Our best estimate of the total emission of $\mathrm{N}_{2} \mathrm{O}$ is based on measured atmospheric abundance (and growth rates) and estimated atmospheric lifetime of $\mathrm{N}_{2} \mathrm{O}$. Currently, the best estimate of the lifetime of $\mathrm{N}_{2} \mathrm{O}$ is roughly 120 years. ${ }^{4}$ Therefore, any error in the calculated atmospheric lifetime leads to a proportionate error in the overall emission rate and the estimated budget of $\mathrm{N}_{2} \mathrm{O}$. Such an error also propagates into the calculated ozone depletion potential and the global 
warming potential of $\mathrm{N}_{2} \mathrm{O}$. The current estimate of the atmospheric lifetime of $\mathrm{N}_{2} \mathrm{O}$ is based on its loss due to stratospheric removal via photolysis and reaction with $\mathrm{O}\left({ }^{1} \mathrm{D}\right)$. Even a small tropospheric loss rate due to reactions with oxidants such as $\mathrm{OH}$ and $\mathrm{NO}_{3}$ would change the calculated atmospheric lifetime with consequences to the estimated emissions of $\mathrm{N}_{2} \mathrm{O}$, its atmospheric budget, its global warming potential and its ozone depletion potential. (The potential reaction of $\mathrm{N}_{2} \mathrm{O}$ with $\mathrm{O}_{3}$ has not been studied but is expected to be very slow.) Therefore, it is important to quantify all potential loss processes. This paper focuses on the potential reaction of $\mathrm{N}_{2} \mathrm{O}$ with $\mathrm{OH}$ and $\mathrm{NO}_{3}$ radicals, two of the ubiquitous oxidants in the troposphere.

The potential reactions of $\mathrm{Cl}$ and $\mathrm{Br}$ atoms with $\mathrm{N}_{2} \mathrm{O}$ could also alter the lifetime of $\mathrm{N}_{2} \mathrm{O}$ since there are non-negligible levels of $\mathrm{Cl}$ and $\mathrm{Br}$ in the troposphere as well as the stratosphere. The rate coefficients for the reactions of $\mathrm{N}_{2} \mathrm{O}$ with $\mathrm{Cl}^{5,6}$ and $\mathrm{Br}^{6-8}$ have been examined at high temperatures by Lesar et al. They have also calculated the barrier heights for these reactions. Based on these results, it is unlikely that the reaction of $\mathrm{Cl}$ atoms would be a significant contributor to $\mathrm{N}_{2} \mathrm{O}$ loss in the troposphere, where the $\mathrm{Cl}$ atom concentrations would be less than $1 \times 10^{4} \mathrm{~cm}^{-3}$ in the troposphere (see for example references 9,10 ) or the stratosphere where the concentrations are slightly $\operatorname{larger}^{11}$ but temperatures are lower. Even though significant concentrations approaching ppt levels of $\mathrm{Br}$ have been observed in localized areas (See for example reference 10), they too are unlikely to contribute significantly. Further studies of the halogen reactions, especially measurements at atmospheric temperatures and more refined quantum calculations, may be warranted. 
Previous studies have attempted to quantify the rate coefficients for the reactions of $\mathrm{N}_{2} \mathrm{O}$ with $\mathrm{OH}$ and $\mathrm{NO}_{3}$ radicals. Four previous studies attempted to measure the rate coefficient for the reaction of $\mathrm{OH}$ with $\mathrm{N}_{2} \mathrm{O}$ :

$$
\mathrm{OH}+\mathrm{N}_{2} \mathbf{O} \stackrel{\mathrm{k}_{1}}{\rightarrow} \text { Products }
$$

Chang and Kaufman ${ }^{12}$ and Atkinson et al. ${ }^{13}$ studied this reaction using the flow tube and flash photolysis techniques, respectively, and placed upper limits of $<4 \times 10^{-16}$ and $<$ $2 \times 10^{-16} \mathrm{~cm}^{3}$ molecule $\mathrm{s}^{-1}$. Gordon and Mulac ${ }^{14}$ placed an upper limit of $<1.7 \times 10^{-14}$ $\mathrm{cm}^{3}$ molecule $\mathrm{s}^{-1}$ using measurements done in a pulsed radiolysis experiment. Biermann et al. ${ }^{15}$ reported rate coefficients for this reaction of $\mathrm{k}_{1}=(3.8 \pm 1.2) \times 10^{-17}$ and $(3.1 \pm 0.8) \times 10^{-17} \mathrm{~cm}^{3}$ molecule ${ }^{-1} \mathrm{~s}^{-1}$ at $298 \mathrm{~K}$ and $283 \mathrm{~K}$, respectively. Fleming et al. ${ }^{16}$ have considered this reaction in an attempt to define lifetimes of $\mathrm{N}_{2} \mathrm{O}$ and placed an upper limit of $<5 \times 10^{-17} \mathrm{~cm}^{3}$ molecule ${ }^{-1} \mathrm{~s}^{-1}$ at $298 \mathrm{~K}$. Clearly, this is a slow reaction, if it occurs at all. However, even the upper limit noted by Fleming et al. would reduce the atmospheric lifetime of $\mathrm{N}_{2} \mathrm{O}$ by nearly 20 years and the calculated emissions would also be $\sim 20 \%$ higher. Very recently, a theoretical study (which was carried out subsequent to the measurement reported here) has placed a very low value $\left(<7 \times 10^{-28}\right.$ $\mathrm{cm}^{3}$ molecule $\mathrm{s}^{-1}$ ) for the rate coefficient for this reaction. ${ }^{17}$

The reaction of $\mathrm{N}_{2} \mathrm{O}$ with $\mathrm{NO}_{3}$

$$
\mathrm{NO}_{3}+\mathrm{N}_{2} \mathrm{O} \stackrel{\mathrm{k}_{2}}{\rightarrow} \text { Products }
$$

is also expected to be very slow. Cantrell et al. ${ }^{18}$ reported an upper limit of $\mathrm{k}_{2}<2 \times 10^{-}$ ${ }^{17} \mathrm{~cm}^{3}$ molecule ${ }^{-1} \mathrm{~s}^{-1}$. Again, such a rate coefficient would significantly alter the estimated lifetime of $\mathrm{N}_{2} \mathrm{O}$ in the atmosphere. Similar to $\mathrm{k}_{1}$, a theoretical study, carried 
out subsequent to our measurements, places a very low value $\left(3 \times 10^{-43} \mathrm{~cm}^{3}\right.$ molecule ${ }^{1} \mathrm{~s}^{-1}$ ) for the rate coefficient for this reaction ${ }^{19}$.

Because rate coefficients for the reactions (1) and (2) are very small, their accurate determination is challenging. However, the analytical capability to measure small reaction rate coefficients, with little or no interferences from secondary reactions, has improved since the above upper limits were reported a few decades ago. For example, the use of pulsed laser photolysis to generate the $\mathrm{OH}$ radical and laser-induced fluorescence to detect them greatly enhanced our ability to minimize photolysis of $\mathrm{N}_{2} \mathrm{O}$ and precisely detect $\mathrm{OH}$ in large concentrations of $\mathrm{N}_{2} \mathrm{O}$. Similarly, we have recently developed a method to study slow reactions of $\mathrm{NO}_{3}$ by using cavity ring down spectroscopy coupled to a very large $\left(7.3 \mathrm{~m}^{3}\right)$ chamber. ${ }^{20,21}$ Furthermore, our ability to measure and quantify impurities using various analytical techniques has improved over the past few decades. Therefore, we undertook this study to more accurately determine $\mathrm{k}_{1}$ and $\mathrm{k}_{2}$.

The reaction of $\mathrm{OH}$ with $\mathrm{N}_{2} \mathrm{O}$ has two potential reactive pathways: ${ }^{17}$

$$
\begin{gathered}
\mathbf{O H}+\mathbf{N}_{\mathbf{2}} \mathbf{O} \stackrel{\mathbf{k}_{1 a}}{\longrightarrow} \mathbf{H O}_{2}+\mathbf{N}_{\mathbf{2}} \quad(1 \mathrm{a}) ; \Delta_{\mathrm{r}} \mathrm{H}^{\mathrm{o}}(298 \mathrm{~K})=-108.0 \mathrm{~kJ} \mathrm{~mol}^{-11} \\
\mathbf{O H}+\mathbf{N}_{\mathbf{2}} \mathbf{O} \stackrel{\mathbf{k}_{1 b}}{\leftrightarrow} \mathbf{O H} \cdot \mathbf{N}_{\mathbf{2}} \mathbf{O} \quad(1 \mathrm{~b}) ; \Delta_{\mathrm{r}} \mathrm{H}^{\mathrm{o}}(0 \mathrm{~K})=+55.2 \mathrm{~kJ} \mathrm{~mol}^{-1}
\end{gathered}
$$

Reaction $1 \mathrm{~b}$, which is reversible addition, ${ }^{17}$ could be followed by abstraction of $\mathrm{H}$ by $\mathrm{O}_{2}$ leading to the same final products, i.e., $\mathrm{HO}_{2}$ and $\mathrm{N}_{2}$. All other reaction pathways are very endothermic and are not important under atmospheric temperatures.

Similarly, the reaction of $\mathrm{NO}_{3}$ with $\mathrm{N}_{2} \mathrm{O}$ has only one exothermic channel: 


$$
\mathrm{N}_{2} \mathrm{O}+\mathrm{NO}_{3} \rightarrow \mathrm{N}_{2}+\mathrm{O}_{2}+\mathrm{NO}_{2} ; \Delta_{\mathrm{r}} \mathrm{H}^{\mathrm{o}}(298 \mathrm{~K})=-122.4 \mathrm{~kJ} \mathrm{~mol}^{-1}
$$

The other possible reactions are endothermic:

$$
\mathrm{N}_{2} \mathrm{O}+\mathrm{NO}_{3} \rightarrow 2 \mathrm{NO}+\mathrm{NO}_{2} ; \Delta_{\mathrm{r}} \mathrm{H}^{\mathrm{o}}(298 \mathrm{~K})=+59.71 \mathrm{~kJ} \mathrm{~mol}^{-1}
$$

and

$$
\mathrm{N}_{2} \mathrm{O}+\mathrm{NO}_{3} \rightarrow \mathrm{N}_{2} \mathrm{O}+\mathrm{NO}+\mathrm{O}_{2} ; \Delta_{\mathrm{r}} \mathrm{H}^{\mathrm{o}}(298 \mathrm{~K})=+16.34 \mathrm{~kJ} \mathrm{~mol}^{-1}(2 \mathrm{c})
$$

Reactions $2 b$ and $2 c$ are endothermic but could be facilitated by the large entropy change. The endothermic Reaction $2 c$, if it occurs at all, will not lead to $\mathrm{N}_{2} \mathrm{O}$ loss; it serves to catalyze $\mathrm{NO}_{3}$ decomposition.

Here, we report the upper limits for the rate coefficient for the reactions of $\mathrm{OH}$ and $\mathrm{NO}_{3}$ with $\mathrm{N}_{2} \mathrm{O}$ and quantify the contributions of these two reactions to the loss of $\mathrm{N}_{2} \mathrm{O}$ in the troposphere. By this quantification, we are able to better constrain the atmospheric lifetime of $\mathrm{N}_{2} \mathrm{O}$ and, hence, its budget.

\section{Experimental Section}

We measured the rate coefficient for the reaction of $\mathrm{OH}$ with $\mathrm{N}_{2} \mathrm{O}$ by following its temporal profile via pulsed laser induced fluorescence subsequent to its pulsedphotolytic production in an excess of $\mathrm{N}_{2} \mathrm{O}$. We followed the temporal profile of $\mathrm{NO}_{3}$ (and $\mathrm{N}_{2} \mathrm{O}_{5}$ in equilibrium with $\mathrm{NO}_{3}$ ) via cavity ring down spectroscopy (CRDS) in the presence of an excess of $\mathrm{N}_{2} \mathrm{O}$ in a large atmospheric simulation chamber. The experimental apparatuses, the procedures, and data analyses are different for these two reactions. Therefore, we will describe them separately. 


\subsection{Measurement of the rate coefficient for the reaction of $\mathrm{OH}$ with $\mathrm{N}_{2} \mathrm{O}$}

The apparatus used to measure $\mathrm{OH}$ reaction rate coefficients via pulsed photolysis have been described in detail in many previous studies ${ }^{22}$ and the specific apparatus used here is also described previously ${ }^{23}$. Therefore, we describe only few details necessary to understand the present study. Further details, including the schematic of the apparatus (Fig. S1), are given in the Supplementary Information.

The apparatus consisted of a jacketed Pyrex cell (volume $=200 \mathrm{~cm}^{3}$ ) through which $\mathrm{N}_{2} \mathrm{O}, \mathrm{H}_{2} \mathrm{O}_{2}$ (used as the $\mathrm{OH}$ precursor), and a bath gas (mostly Ar) were introduced using calibrated mass flow controllers. Water (for temperature above 298 K) or pure ethanol (for temperatures below $298 \mathrm{~K}$ ) was flowed through the outer jacket of the reactor to achieve the desired temperature $(\mathrm{T}=253-372 \mathrm{~K})$. The temperature of the gas mixture flowing through the reactor in the reaction zone (defined as the volume where the photolysis and the probe beams intersect) was measured using a retractable thermocouple.

$\mathrm{H}_{2} \mathrm{O}_{2}$ was photolyzed by a $248 \mathrm{~nm} \mathrm{KrF}$ excimer laser to produce an initial $\mathrm{OH}$ concentration, $[\mathrm{OH}]_{0}$, of typically around $10^{11} \mathrm{~cm}^{-3}$. A Nd: YAG-pumped frequency-doubled dye laser was used to excite the $\mathrm{OH}$ radical $\left(\mathrm{X}^{2} \Pi \mathrm{v} "=0 \rightarrow\right.$ $\left(\mathrm{A}^{2} \Sigma^{+} \mathrm{v}^{\prime}=1\right)$ at $\lambda \cong 282 \mathrm{~nm}$. The resulting fluorescence around $308 \mathrm{~nm}$ from $\left(\mathrm{A}^{2} \Sigma^{+} \mathrm{v}^{\prime}=1\right) \rightarrow\left(\mathrm{X}^{2} \Pi \mathrm{v}^{\prime \prime}=1\right)$ and $\left(\mathrm{A}^{2} \Sigma^{+} \mathrm{v}^{\prime}=0\right) \rightarrow\left(\mathrm{X}^{2} \Pi \mathrm{v}^{\prime \prime}=0\right)$ was then detected by a photomultiplier tube positioned orthogonally to the two laser beams. The signal from the PM tube was processed through a gated charge integrator and fed to a 
computer. The time delay between the excimer and probe lasers were varied to change the reaction time.

The determination of the rate coefficient of a very slow reaction is challenging mainly because we need to use very high concentrations of $\mathrm{N}_{2} \mathrm{O}$, the excess reagent. The high concentrations of $\mathrm{N}_{2} \mathrm{O}$ very rapidly quench the $\mathrm{OH}$ fluorescence signal. The collected $\mathrm{OH}$ fluorescence was first passed through a bandpass filter centered at $310 \mathrm{~nm}$ with a full width at half maximum (FWHM) of $10 \mathrm{~nm}$ (with transmission $>70 \%$ at $310 \mathrm{~nm}$ ) before reaching the photomultiplier tube. Scattered light from the $282 \mathrm{~nm}$ laser beam inside the cell (and any fluorescence it caused in the cell), was reduced almost to undetectable levels by rotating the beam polarization from horizontal to vertical with a $\lambda / 2$ wave plate before entering the cell, installing an exit window at Brewster angle and dumping the beam into a beam dump to minimize back scatter. This arrangement greatly reduced the scattered light and we could detect $1 \times 10^{9} \mathrm{OH}$ $\mathrm{cm}^{-3}$ for integration of 100 pulses in 50 torr of $\mathrm{N}_{2} \mathrm{O}$ with a signal to noise of unity. All experiments were carried out under pseudo-first order conditions in $[\mathrm{OH}]$ by maintaining the concentrations of $\mathrm{N}_{2} \mathrm{O}$ much larger than $[\mathrm{OH}]_{0}$, the initial hydroxyl radical concentrations; i.e., $\left[\mathrm{N}_{2} \mathrm{O}\right] \gg[\mathrm{OH}]_{0}$. The temporal profiles of $[\mathrm{OH}]$, therefore, followed a first order rate law:

$$
[\mathrm{OH}]_{\mathrm{t}}=[\mathrm{OH}]_{0} \mathrm{e}^{-\mathrm{k}^{\prime} \mathrm{t}} ; \text { where } \mathrm{k}^{\prime}=\mathrm{k}_{1}\left[\mathrm{~N}_{2} \mathrm{O}\right]+\mathrm{k}_{0}^{\prime}
$$

$\mathrm{k}^{\prime}$ is the first-order decay rate, $\mathrm{k}_{1}$ is the bimolecular rate coefficient for reaction (1). $\mathrm{k}_{0}{ }_{0}$ is the rate coefficient for $\mathrm{OH}$ removal in the absence of $\mathrm{N}_{2} \mathrm{O}$; it 
is expressed as a first order rate coefficient. This loss process is due to a combination of diffusion of $\mathrm{OH}$ out of the reaction zone and reactions of $\mathrm{OH}$ with $\mathrm{H}_{2} \mathrm{O}_{2}$ and impurities in the bath gas. The concentration of $\mathrm{OH}$ at various reaction times were determined by changing the delay between the photolysis and probe lasers, recording the fluorescence signal at 10 to 20 different delay times and averaging signals from up to 300 probe laser pulses for each delay time. The LIF signal detected by the photomultiplier tube was captured using homemade electronics and a LabView program. A non-linear least-squares analysis was used to fit the fluorescence signal versus time data to Equation (I) to extract the values of $\mathrm{k}^{\prime}$. The second-order rate coefficients were obtained from linear least squares analysis of the $\mathrm{k}^{\prime}$ values determined at various $\mathrm{N}_{2} \mathrm{O}$ concentrations. Typical first order fluorescence signal and plots of $k^{\prime}$ vs $\left[\mathrm{N}_{2} \mathrm{O}\right]$ are shown in the Supplementary Information.

Both the photolysis and probe lasers were operated at $10 \mathrm{~Hz}$ and their energies were measured by laser power monitors situated at the exits of the cell, (13-44) $\mathrm{mJ} \mathrm{cm}^{-2}$. They remained constant during the course of measuring a given $\mathrm{OH}$ temporal profile. Between 2 and 55 Torr of $\mathrm{N}_{2} \mathrm{O}$ was added to a large flow of Ar for a total pressure of 500 Torr in the reactor. This mixture was flowed through the reaction cell $\left(0.09\right.$ to $\left.27 \mathrm{~cm} \mathrm{~s}^{-1}\right)$ such that a given aliquot of the gas mixture was exposed to only a few laser pulses; most often, they were exposed to only one photolysis laser pulse. 
The concentrations of gases inside were calculated from the measured flow rates of gases using calibrated electronic mass flow controllers and the measured temperature and pressure in the reaction cell. Pressure was determined using a calibrated capacitance manometer. The electronic mass flow meters were calibrated by measuring the rate of pressure rise when a given gas flowed through the mass flow controller into a known volume. Partial pressures of the gases were computed from the mass flow rates and the total cell pressure. The estimated uncertainty in $\mathrm{N}_{2} \mathrm{O}$ concentration in the reactor is better than $5 \%$.

\subsection{Measurement of rate coefficient for the reaction of $\mathrm{NO}_{3}$ with $\mathrm{N}_{2} \mathrm{O}$}

The rate coefficient for the reaction of $\mathrm{NO}_{3}$ with $\mathrm{N}_{2} \mathrm{O}$ was measured at room temperature $(298.0 \pm 1.5 \mathrm{~K})$ in the ICARE-7300L Teflon chamber and at atmospheric pressure $(1000 \pm 5$ hpa) (shown in the Supplementary Information as Fig. S2). This chamber, the CRDS detection of $\mathrm{NO}_{3}$ and $\mathrm{N}_{2} \mathrm{O}_{5}$, the related gas handling system, and the procedures used to measure rate coefficients have been described in detail in our previous work. ${ }^{24,25}$ The method and procedure used here were very similar to those described earlier. Therefore, only information necessary to understand the present work is given here.

During kinetics studies, a flow (about $10 \mathrm{~L} \mathrm{~min}^{-1}$ ) of purified air was added to maintain the chamber slightly above atmospheric pressure and compensate for the pressure reduction caused by the continuous withdrawal of the gas mixture from the chamber for analysis. Maintaining the pressure slightly above ambient also prevented 
any room air from leaking into the chamber. The chamber contents were mixed by two fans within the chamber. The dilution rate and mixing time in the chamber were measured by injecting a sample of $\mathrm{SF}_{6}(>99.99 \%$, Alpha Gaz) into the chamber and measuring its temporal profile using a FTIR spectrometer. In this study, the dilution rate (expressed as a first order rate coefficient) was $2.3 \times 10^{-5} \mathrm{~s}^{-1}$ and the mixing time (for $>99 \%$ mixing) was less than 30s. The key analytical instruments used in this study are the commercial Nicolet 5700 Magna FT-IR spectrometer and a two-channel Cavity Ring Down Spectrometer. ${ }^{25}$ The IR spectra of the gas mixture in the chamber were recorded by co-adding 16 scans at a spectral resolution of $1 \mathrm{~cm}^{-1}$ (path length of 140 m). The time resolution with this measurement was 2 mins. $\mathrm{N}_{2} \mathrm{O}$ and $\mathrm{SF}_{6}$ were monitored, respectively, at $2620 \mathrm{~cm}^{-1}-2410 \mathrm{~cm}^{-1}$ and $954 \mathrm{~cm}^{-1}-934 \mathrm{~cm}^{-1}$. The integrated absorbances (peak areas) were used for calibration (See Fig. S3) which enabled determining the concentrations of $\mathrm{N}_{2} \mathrm{O}$ in the reactor.

A two-channel cavity ring down spectrometer operating at $662 \mathrm{~nm}$ was used to simultaneously measure the concentrations of $\mathrm{NO}_{3}$ (in one channel) and $\mathrm{N}_{2} \mathrm{O}_{5}+\mathrm{NO}_{3}$ (in another channel). The time resolution of the instrument was $1 \mathrm{~s}$ with detection sensitivities of roughly 0.4 and 2 pptv for $\mathrm{NO}_{3}$ and $\mathrm{N}_{2} \mathrm{O}_{5}$ for 1 second integration, respectively, as described in detail by Fuchs et al. ${ }^{26}$ Since we used roughly a ppbv of $\mathrm{NO}_{3}$ and a few ppbv of $\mathrm{N}_{2} \mathrm{O}_{5}$, the signal to noise ratios for kinetics experiments were excellent. The gas sample entering the CRDS system was passed through a filter to remove any aerosols present in the chamber and thus minimize scatter of the $662 \mathrm{~nm}$ light that degrades the signal. The total loss of $\mathrm{NO}_{3}$ and $\mathrm{N}_{2} \mathrm{O}_{5}$ to the walls of the CRDS 
instrument and the filter have been estimated ${ }^{26-28}$ to be less than $20 \%$ and $4 \%$, respectively, for $\mathrm{NO}_{3}$ and $\mathrm{N}_{2} \mathrm{O}_{5}$; these losses were accounted for in calculating the concentrations. The uncertainties in measuring the concentrations and rate coefficients are described in previous publications. ${ }^{25}$ As described previously, even though we studied reaction 2 under pseudo first order conditions in $\mathrm{NO}_{3}$, we need the absolute concentration since $\mathrm{NO}_{3}$ is tightly coupled to $\mathrm{N}_{2} \mathrm{O}_{5}$ in the system through its equilibrium,

$$
\begin{aligned}
& \mathrm{N}_{2} \mathrm{O}_{5} \stackrel{\mathrm{k}_{3}}{\longrightarrow} \mathrm{NO}_{3}+\mathrm{NO}_{2} \\
& \mathrm{NO}_{3}+\mathrm{NO}_{2} \stackrel{\mathrm{k}_{4}}{\longrightarrow} \mathrm{N}_{2} \mathrm{O}_{5}
\end{aligned}
$$

The rate coefficients for the reactions of $\mathrm{NO}_{3}$ radicals with $\mathrm{N}_{2} \mathrm{O}$ were measured by following the temporal profiles of $\mathrm{NO}_{3}$ and $\mathrm{N}_{2} \mathrm{O}_{5}$ in an excess of $\mathrm{N}_{2} \mathrm{O}$. The rate coefficient $\mathrm{k}_{2}$ was obtained by simultaneously fitting the temporal profiles of $\mathrm{NO}_{3}$ and $\mathrm{N}_{2} \mathrm{O}_{5}$.

First, $\mathrm{N}_{2} \mathrm{O}_{5}$ was injected into the chamber to generate $\mathrm{NO}_{3}$ (and $\mathrm{NO}_{2}$ ). An equilibrium among $\mathrm{NO}_{3}, \mathrm{NO}_{2}$, and $\mathrm{N}_{2} \mathrm{O}_{5}$ (Reactions 3 and 4 below) was set up rapidly and maintained throughout the course of kinetics studies. The initial mixing ratios of $\mathrm{N}_{2} \mathrm{O}_{5}$ were varied between 8 and $25 \mathrm{ppbv}$ and the resulting initial mixing ratios of $\mathrm{NO}_{3}$ were between 0.5 and $2.5 \mathrm{ppbv}$. The concentrations of $\mathrm{NO}_{3}$ and $\mathrm{N}_{2} \mathrm{O}_{5}$ were measured for 10 mins to observe their losses in the chamber due to wall loss, dilution, and reactions with any impurities. The measured temporal profiles were fit by using a model that integrated the following set of reactions occurring in the chamber to derive the time dependence of $\mathrm{NO}_{3}, \mathrm{~N}_{2} \mathrm{O}_{5}$ and $\mathrm{NO}_{2}$, as described previously: ${ }^{25}$ 


$$
\begin{array}{r}
\mathrm{N}_{2} \mathrm{O}_{5} \stackrel{\mathrm{k}_{3}}{\longrightarrow} \mathrm{NO}_{3}+\mathrm{NO}_{2} \\
\mathrm{NO}_{3}+\mathrm{NO}_{2} \stackrel{\mathrm{k}_{4}}{\longrightarrow} \mathrm{N}_{2} \mathrm{O}_{5} \\
\mathrm{NO}_{3} \stackrel{\mathrm{k}_{5}}{\longrightarrow} \text { loss } \\
\mathrm{N}_{2} \mathrm{O}_{5} \stackrel{\mathrm{k}_{6}}{\longrightarrow} \text { loss }
\end{array}
$$

The fitting was carried out by simultaneously minimizing the sum of least-squares for both $\mathrm{NO}_{3}$ and $\mathrm{N}_{2} \mathrm{O}_{5}$ profiles by changing the initial concentrations of each reactant and reaction rate coefficients of each reaction as input parameters. The values of the rate coefficients for the reactions involved in the equilibrium are well known. The equilibrium constant, $\mathrm{k}_{\mathrm{eq}}=\left[\mathrm{N}_{2} \mathrm{O}_{5}\right] /\left[\mathrm{NO}_{3}\right]\left[\mathrm{NO}_{2}\right]=\mathrm{k}_{4} / \mathrm{k}_{3}, \mathrm{k}_{3}$, and $\mathrm{k}_{4}$ were taken from NASA/JPL recommendation. ${ }^{11}$ We varied $\mathrm{k}_{4}$ by less than $5 \%$ to improve the fits since a small uncertainty in temperature makes a significant difference in the fit. However, the equilibrium constant that was used was always within 5\%, the difference expected for a temperature variation of about $0.5 \mathrm{~K}$. Using this procedure, the best values for the loss rate coefficients $\mathrm{k}_{5}$ and $\mathrm{k}_{6}$ in the absence of $\mathrm{N}_{2} \mathrm{O}$ (usually termed "wall loss rate coefficients") were derived from the fit.

Once the data for wall loss rate coefficients were derived, a known concentration of $\mathrm{N}_{2} \mathrm{O}$ (from FTIR measurements) was added to the chamber and the loss rates of $\mathrm{N}_{2} \mathrm{O}_{5}$ and $\mathrm{NO}_{3}$ were monitored for up to 60 mins.

$$
\mathrm{N}_{2} \mathrm{O}+\mathrm{NO}_{3} \stackrel{\mathrm{k}_{2}}{\longrightarrow} \text { Products }
$$

The measured profiles of $\mathrm{NO}_{3}$ and $\mathrm{N}_{2} \mathrm{O}_{5}$ were again fit by varying $\mathrm{k}_{2}$ while keeping all the other rate coefficients the same as those determined in the previous steps. The best 
value of the rate coefficient was obtained by fitting both $\mathrm{NO}_{3}$ and $\mathrm{N}_{2} \mathrm{O}_{5}$ profiles (i.e., by minimizing the sum of least-squares for both $\mathrm{NO}_{3}$ and $\mathrm{N}_{2} \mathrm{O}_{5}$ profiles simultaneously).

\subsection{Materials used in this study}

Argon (> 99.9999\%, Air Liquide) and $\mathrm{SF}_{6}$ (> 99.999\%, Air Liquide) were used without further purification. Two samples of $\mathrm{N}_{2} \mathrm{O}$ (from Air Liquide) with stated purities of $99 \%$ (industrial) and $99.998 \%$ were used for all experiments. Since impurity levels in the $\mathrm{N}_{2} \mathrm{O}$ samples were not given by the vendors, we analysed them using a Proton Transfer Reaction Time-of-Flight Mass spectrometer (Ionicon PTR-ToF-MS 8000) for reactive hydrocarbons, Fourier Transform Infrared Spectroscopy (ThermoFischer FTIR) for hydrocarbons and other potential impurities such as $\mathrm{CO}$ and $\mathrm{CO}_{2}$, Cavity Ring-Down Spectroscopy (CRDS), a NOx monitor, and an Aerodyne CAPS $\mathrm{NO}_{2}$ monitor for $\mathrm{NO}_{2}$. The measured impurity levels were: $\mathrm{H}_{2} \mathrm{O}<3 \mathrm{ppm}, \mathrm{O}_{2}<2 \mathrm{ppm}$, $\mathrm{C}_{\mathrm{n}} \mathrm{H}_{\mathrm{m}}<1 \mathrm{ppm}, \mathrm{CO}<1 \mathrm{ppm}, \mathrm{CO}_{2}<2 \mathrm{ppm}, \mathrm{H}_{2}<0.1 \mathrm{ppm}$ (specified by vendor), $\mathrm{N}_{2}<$ $10 \mathrm{ppm}$ (specified by vendor), $\mathrm{NO}_{\mathrm{x}}\left(\mathrm{NO}+\mathrm{NO}_{2}\right)<1 \mathrm{ppb}$, and $\mathrm{NO}_{2}<1 \mathrm{ppm}$. It should be noted that any $\mathrm{NO}$ would be quickly removed in the experiments involving $\mathrm{NO}_{3}$ and thus would not affect the $\mathrm{N}_{2} \mathrm{O}$ rate coefficient measurement. Details are given in the SI. $\mathrm{N}_{2}$ had a stated purity of (> $99.9999 \%$, Air Liquide) and was used as supplied. A 35 wt.\% $\mathrm{H}_{2} \mathrm{O}_{2}$ solution was obtained from Prolabo and was concentrated by bubbling helium (Air Liquide, $\geq 99.9999 \%$ ) through the solution for several days prior to use to remove water and obtain concentrated $(\sim 90 \%) \mathrm{H}_{2} \mathrm{O}_{2}$. Either $\mathrm{Ar}$ or $\mathrm{N}_{2}$ was flowed constantly through the $\mathrm{H}_{2} \mathrm{O}_{2}$ sample to keep it as pure as possible. Pure $\mathrm{N}_{2} \mathrm{O}_{5}$ was 
synthesized by mixing $\mathrm{NO}$ with $\mathrm{O}_{3}$ in a slow flow and collecting $\mathrm{N}_{2} \mathrm{O}_{5}$ in a trap at 193 $\mathrm{K}$ and purifying the sample, as described by Davidson et al. ${ }^{29}$.

\section{Results and Discussion}

In this study we measured $\mathrm{k}_{1}$ and $\mathrm{k}_{2}$ using two experimental apparatuses. The methods used for the analyses of the two rate coefficients are different. Further, the previous studies of these two reactions come from studies that were essentially focused on $\mathrm{OH}$ reaction or $\mathrm{NO}_{3}$ reactions. Therefore, we will present and discuss the results of the two reaction rate coefficients separately.

\subsection{Reaction of $\mathrm{OH}$ with $\mathrm{N}_{2} \mathrm{O}$}

As a test of our ability to measure small rate coefficients, we first measured the well-known rate coefficient for the reaction $\mathrm{OH}$ with $\mathrm{CH}_{4}$ :

$$
\mathrm{OH}+\mathrm{CH}_{4} \stackrel{\mathrm{k}_{7}}{\rightarrow} \mathrm{CH}_{3}+\mathrm{H}_{2} \mathrm{O}
$$

We obtained a value of $\mathrm{k}_{7}=(6.19 \pm 0.04) \times 10^{-15} \mathrm{~cm}^{3}$ molecule $\mathrm{e}^{-1} \mathrm{~s}^{-1}(2 \sigma$ precision only) at $298 \mathrm{~K}$. When we include the uncertainty in the measurement of $\mathrm{CH}_{4}$ concentration, we obtained a value of $\mathrm{k}_{7}=(6.19 \pm 0.31) \times 10^{-15} \mathrm{~cm}^{3}$ molecule $^{-1} \mathrm{~s}^{-}$ ${ }^{1}$, in excellent agreement with the current recommendations of NASA/JPL ${ }^{11}$ and IUPAC panels ${ }^{30}$, respectively, of $6.3 \times 10^{-15}$ and $6.4 \times 10^{-15} \mathrm{~cm}^{3}$ molecule ${ }^{-1} \mathrm{~s}^{-1}$. It is also in excellent agreement with the original measurements of Vaghjiani and Ravishankara ${ }^{22}$ of $(6.25 \pm 0.12) \times 10^{-15} \mathrm{~cm}^{3}$ molecule $\mathrm{s}^{-1}$ as well as that of Mellouki et al., ${ }^{23}(6.34 \pm 0.56) \times 10^{-15} \mathrm{~cm}^{3}$ molecule ${ }^{-1} \mathrm{~s}^{-1}$, using a previous version 
of the apparatus used here. Therefore, we are confident of our $\mathrm{OH}$ reaction kinetics capabilities.

The measured $\mathrm{OH}$ loss temporal profiles in the presence of $\mathrm{N}_{2} \mathrm{O}$ were always exponential (Fig. S4). A high pressure of Ar (500 Torr) was used as a bath gas for all measurements. Use of $\mathrm{Ar}$, which does not quench $\mathrm{OH}$ fluorescence significantly, reduced the changes in diffusive loss of $\mathrm{OH}$ when large concentrations of $\mathrm{N}_{2} \mathrm{O}$ were added to the reactor. Fig. 1 shows a plot of the measured pseudo-first-order rate coefficient for the loss of $\mathrm{OH}$ as a function of $\mathrm{N}_{2} \mathrm{O}$ concentration at 253, 298 and 372 K. For greater clarity the data obtained at $372 \mathrm{~K}$ is shown in the inset to the figure. Clearly, the slopes of these plots are negative and statistically different from zero. We attribute this slightly negative value to the reduction in $\mathrm{OH}$ loss rate from the reaction zone as $\mathrm{N}_{2} \mathrm{O}$ concentration increases (even in the presence of 500 Torr of Ar) and further hinders diffusion out of the reaction zone. To test this hypothesis, we replaced $\mathrm{N}_{2} \mathrm{O}$ by $\mathrm{N}_{2}$, which does not react with $\mathrm{OH}$ but has a larger collision diameter than Ar to reduce the diffusion out of the reaction zone. Clearly, we see a very similar behaviour of decreasing k' with increasing $\mathrm{N}_{2}$ concentrations. Furthermore, use of $\mathrm{He}$ in preliminary experiments showed much larger decreases in k' upon addition of $\mathrm{N}_{2} \mathrm{O}$. These observations add confidence to our attribution of the negative value of the slope to the reduced diffusive loss of $\mathrm{OH}$ when $\mathrm{N}_{2} \mathrm{O}$ is added to the reactor.

The only way to observe a negative rate coefficient is for a slow generation of $\mathrm{OH}$ (more than what is consumed by reactions with $\mathrm{H}_{2} \mathrm{O}_{2}$ and impurities) due to some reaction subsequent to the photolytic production $\mathrm{OH}$ in the presence of 
$\mathrm{N}_{2} \mathrm{O}$. The quantum yield for the production of $\mathrm{OH}$ in the photodissociation of $\mathrm{H}_{2} \mathrm{O}_{2}$ is known to be $2 .{ }^{11}$ Other potential radicals that could be produced are $\mathrm{O}$ (from $\mathrm{N}_{2} \mathrm{O}$ or $\mathrm{H}_{2} \mathrm{O}_{2}$ photolysis), ${ }^{11}$ atoms and $\mathrm{HO}_{2}$ radicals (from $\mathrm{H}_{2} \mathrm{O}_{2}$ photolysis). ${ }^{31}$ With the known quantum yields for the production of $\mathrm{O}, \mathrm{H}$, and $\mathrm{HO}_{2}$, we estimate that at most $10^{8} \mathrm{~cm}^{-3}$ of these reactive species could be produced in our system. The contribution of $\mathrm{N}_{2} \mathrm{O}$ photolysis is negligible (either via one or two photon dissociation). These radicals are not known to react rapidly with $\mathrm{N}_{2} \mathrm{O}$ or with $\mathrm{H}_{2} \mathrm{O}_{2}$. Even if they did, their concentrations are such that they could not influence the measured temporal profiles. To experimentally check for this possibility, we varied the photolysis laser fluence, initial $\mathrm{OH}$ concentration, $\mathrm{H}_{2} \mathrm{O}_{2}$ concentration, and linear flow velocity of the gas through the reactor. The obtained values of $\mathrm{k}_{1}$ were independent of these variations, demonstrating the absence of significant errors due to secondary reactions in our measurements.

There are other potential reactions that could lead to the slow regeneration of $\mathrm{OH}$. The $\mathrm{HO}_{2}$ radical (produced by $\mathrm{OH}$ reaction with $\mathrm{H}_{2} \mathrm{O}_{2}$ ) could react with $\mathrm{O}, \mathrm{H}$, or $\mathrm{NO}$ (either present as an impurity in $\mathrm{N}_{2} \mathrm{O}$ or produced via photolysis of $\mathrm{N}_{2} \mathrm{O}$ followed by the reaction of $\mathrm{O}\left({ }^{1} \mathrm{D}\right)$ with $\left.\mathrm{N}_{2} \mathrm{O}\right)$. Therefore, we carefully measured the NO impurity in $\mathrm{N}_{2} \mathrm{O}$ and found it to be less than 1 ppbv; therefore the concentration of $\mathrm{NO}$ in the reaction mixture was no more than $0.1 \mathrm{ppbv}$ (or $\left.<2.5 \times 10^{9} \mathrm{~cm}^{-3}\right)$ in the reactor. The photolytic production of NO from the 248 $\mathrm{nm}$ photolysis of $\mathrm{N}_{2} \mathrm{O}$ was calculated to be less than $2 \times 10^{11} \mathrm{~cm}^{-3}$ at the laser fluences used here. Even if this level of NO were generated, it could not 
reproduce $\mathrm{OH}$ during the time scale of the measurements. Furthermore, we varied the laser fluence by almost a factor of 3 with no discernible $(<5 \%)$ changes and within the precision of our measurements). This test also excludes any twophoton photolysis of $\mathrm{N}_{2} \mathrm{O}$ that could generate NO. Similarly, the calculated $\mathrm{O}$ and $\mathrm{H}$ atoms concentrations are $<10^{8} \mathrm{~cm}^{3}$. To check for any such secondary reactions, we modelled a set of reactions shown below.

$$
\begin{array}{r}
\mathrm{OH}+\mathrm{H}_{2} \mathrm{O}_{2} \rightarrow \mathrm{H}_{2} \mathrm{O}+\mathrm{HO}_{2} \\
\mathrm{OH}+\mathrm{HO}_{2} \rightarrow \mathrm{H}_{2} \mathrm{O}+\mathrm{O}_{2} \\
\mathrm{OH} \rightarrow \text { loss by diffusion } \\
\mathrm{OH}+\mathrm{N}_{2} \mathrm{O} \rightarrow \mathrm{HO}_{2}+\mathrm{N}_{2} \\
\mathrm{~N}_{2} \mathrm{O}+\mathrm{h} v \rightarrow \mathrm{N}_{2}+\mathrm{O}(1 \mathrm{D}), \lambda<337 \mathrm{~nm} \\
\mathrm{O}(1 \mathrm{D})+\mathrm{H}_{2} \mathrm{O} \rightarrow 2 \mathrm{OH} \\
\mathrm{O}(1 \mathrm{D})+\mathrm{N}_{2} \mathrm{O} \rightarrow 2 \mathrm{NO} \\
\mathrm{O}(1 \mathrm{D})+\mathrm{N}_{2} \mathrm{O} \rightarrow \mathrm{N} 2+\mathrm{O}^{2} \\
\mathrm{NO}+\mathrm{HO}_{2} \rightarrow \mathrm{OH}+\mathrm{NO}_{2}
\end{array}
$$

The results showed that we could not regenerate $\mathrm{OH}$ in the time scale of our experiments. The contributions of other reactive impurities, if present, would only lead to an over estimation of the measured rate coefficient.

We obtained the upper limits for the rate coefficients at each temperature by fitting all pseudo-first-order rate coefficients at a given temperature to a straight 
line using unweighted linear least squares routine and then adding the $2 \sigma$ uncertainties in the fit (Table 1). Table 1 lists the slopes of the plots shown in Fig. $1\left(\mathrm{k}_{1}\right)$ along with the experimental conditions used in their determination. An alternative way to estimate the rate coefficient is to compare the measured "negative" rate coefficient with that measured with $\mathrm{N}_{2}$ (a non-reacting molecule). We took the difference between values measured in $\mathrm{N}_{2} \mathrm{O}$ with that in $\mathrm{N}_{2}$ and added twice the standard deviations in the measured value to the difference. This approach yields $\mathrm{k}_{1}=$ $(6.0 \pm 2.6) \times 10^{-18}$ and $(4.2 \pm 0.7) \times 10^{-18} \mathrm{~cm}^{3}$ molecule $^{-1} \mathrm{~s}^{-1}$ at $253 \mathrm{~K}$ and $298 \mathrm{~K}$, respectively. Therefore, we suggest that the upper limit for the rate coefficient for this reaction is $\mathrm{k}_{1}<1 \times 10^{-17} \mathrm{~cm}^{3}$ molecule $\mathrm{e}^{-1} \mathrm{~s}^{-1}$ at all the temperatures measured.

Table 1. Summary of experimental conditions and measured values for the rate coefficients, $\mathrm{k}_{1}(\mathrm{~T})$, for the $\mathrm{OH}+\mathrm{N}_{2} \mathrm{O}$ reaction. These values are denoted with an asterisk since we attribute them to effect of $\mathrm{N}_{2} \mathrm{O}$ on $\mathrm{OH}$ diffusion rather than reaction with $\mathrm{OH}$.

\begin{tabular}{|c|c|c|c|c|c|c|c|}
\hline $\begin{array}{c}\mathrm{T} \\
(\mathrm{K})\end{array}$ & $\begin{array}{c}\text { Pressure of Ar } \\
\text { (Torr) }\end{array}$ & $\begin{array}{c}{\left[\mathrm{N}_{2} \mathrm{O}\right]} \\
\left(10^{17} \mathrm{~cm}^{-3}\right)\end{array}$ & $\begin{array}{c}{\left[\mathrm{H}_{2} \mathrm{O}_{2}\right]} \\
\left(10^{13} \mathrm{~cm}^{-3}\right)\end{array}$ & $\begin{array}{c}{[\mathrm{OH}]_{0}} \\
\left(10^{11} \mathrm{~cm}^{-3}\right)\end{array}$ & $\begin{array}{l}\text { Fluence } \\
\mathrm{mJ} \mathrm{cm}^{-2}\end{array}$ & \multicolumn{2}{|c|}{$\begin{array}{r}\mathrm{k}_{1} \\
3 \mathrm{mo}\end{array}$} \\
\hline & & & & & & Measured & $\begin{array}{l}\text { Upper } \\
\text { limit }\end{array}$ \\
\hline $\begin{array}{l}253 \\
253\end{array}$ & $\begin{array}{l}500(99 \%) \\
500(99.998 \%)\end{array}$ & $\begin{array}{l}0.62-14.30 \\
1.41-10.52\end{array}$ & $\begin{array}{l}2.12-3.75 \\
3.18-3.89\end{array}$ & $\begin{array}{l}0.81-1.42 \\
3.12-3.82\end{array}$ & $\begin{array}{l}17 \\
16\end{array}$ & $-0.91 \pm 0.39$ & $<0.88$ \\
\hline $\begin{array}{l}298 \\
298\end{array}$ & $\begin{array}{l}500(99 \%) \\
500(99.998 \%)\end{array}$ & $\begin{array}{l}0.44-17.60 \\
1.27-10.42\end{array}$ & $\begin{array}{l}2.57-4.22 \\
3.50-4.40\end{array}$ & $\begin{array}{l}2.42-3.96 \\
3.44-4.32\end{array}$ & $\begin{array}{c}34-44 \\
17\end{array}$ & $-1.09 \pm 0.34$ & $<0.49$ \\
\hline 372 & $500(99 \%)$ & $0.44-8.52$ & $3.00-5.40$ & $2.21-5.30$ & $33-44$ & $-2.26 \pm 1.34$ & $<0.38$ \\
\hline
\end{tabular}


All quoted uncertainties are $2 \sigma$ from the precision of the least-squares analysis of k' versus $\left[\mathrm{N}_{2} \mathrm{O}\right]$.

Comparison with literature values: Gordon and Mulac ${ }^{14}$ followed the temporal profile of $\mathrm{OH}$ via resonance absorption following pulsed radiolytic production of $\mathrm{OH}$ in the presence of $\mathrm{N}_{2} \mathrm{O}$ and reported an upper limit of $\mathrm{k}_{1}<1.7 \times 10^{-14} \mathrm{~cm}^{3}$ molecule ${ }^{-1} \mathrm{~s}^{-1}$ at 440 K. Atkinson et al. ${ }^{13}$ reported an upper limit of $<2 \times 10^{-16} \mathrm{~cm}^{3}$ molecule ${ }^{-1} \mathrm{~s}^{-1}$ at both 298 $\mathrm{K}$ and $442.8 \mathrm{~K}$ using the pulsed photolysis-resonance fluorescence technique. Chang and Kaufman ${ }^{12}$ failed to measure an observable enhancement in $\mathrm{OH}$ loss rates in the presence of $\mathrm{N}_{2} \mathrm{O}$ in their flow tube reactor and place an upper limit of $<4 \times 10^{-16} \mathrm{~cm}^{3}$ molecule $\mathrm{e}^{-1} \mathrm{~s}^{-1}$. Our values are lower than these three reports but consistent with them given that they are all upper limits.

However, Biermann et al. ${ }^{15}$ reported $\mathrm{k}_{1}=(3.8 \pm 1.2) \times 10^{-17}$ and $(3.1 \pm 0.8) \times 10^{-17}$ $\mathrm{cm}^{3}$ molecule $\mathrm{s}^{-1}$ at $298 \mathrm{~K}$ and $283 \mathrm{~K}$, respectively. They used long path resonance absorption detection of $\mathrm{OH}$ subsequent to its production via water photolysis using a synchronized bank of flash lamps in their long cell. They reported that the measured first order rate coefficients for the loss of $\mathrm{OH}$ increased linearly with $\mathrm{N}_{2} \mathrm{O}$ concentration and derived the values noted above. Our results are not consistent with this reported rate coefficient. We suspect that $\mathrm{N}_{2} \mathrm{O}$ was photolyzed in their reactor since they used $\mathrm{LiF}$ windows on their photolysis lamps that would have allowed photolysis wavelengths down to $\sim 115 \mathrm{~nm}$ into their reactor. With the short wavelength radiation, 
$\mathrm{N}_{2} \mathrm{O}$ would have been photolyzed and the subsequent reaction of $\mathrm{O}\left({ }^{1} \mathrm{D}\right)$ with $\mathrm{N}_{2} \mathrm{O}$ would produce NO. Since they used Ar as the bath gas, only a small fraction of the $\mathrm{O}\left({ }^{1} \mathrm{D}\right)$ would have been quenched and large concentrations of NO would have been produced. (Note that the rate coefficient for the quenching of $\mathrm{O}\left({ }^{1} \mathrm{D}\right)$ by $\mathrm{Ar}$ is about 100 times smaller than that by $\mathrm{N}_{2} \mathrm{O}$ ). The extent of $\mathrm{NO}$ production would increase linearly with $\mathrm{N}_{2} \mathrm{O}$ concentration such that it could appear that the measured first order rate coefficient for the loss of $\mathrm{OH}$ increased with $\mathrm{N}_{2} \mathrm{O}$ abundance. We cannot accurately calculate the extent of NO production in their system but based on their reported initial concentration of $[\mathrm{OH}]_{0}$ and water vapor pressure, we suspect that more than $1 \times 10^{13} \mathrm{~cm}^{-3}$ of NO would have been produced in 75 Torr of $\mathrm{N}_{2} \mathrm{O}$ per photolysis flash. If they could generate as much as $1 \times 10^{14} \mathrm{~cm}^{-3}$ of $\mathrm{NO}$, the reaction of $\mathrm{OH}$ with $\mathrm{NO}$ would account for their observed $\mathrm{OH}$ loss rates, increasing linearly with increasing $\mathrm{N}_{2} \mathrm{O}$ concentration as $\mathrm{NO}$ production increased and $\mathrm{OH}$ loss increased due to the reaction of $\mathrm{NO}$ with $\mathrm{OH}$. However, for this explanation, the third body efficiency of $\mathrm{N}_{2} \mathrm{O}$ in the $\mathrm{OH}+\mathrm{NO}+\mathrm{M}$ reaction has to be similar to that of $\operatorname{Ar}$ (otherwise, they would have likely seen a quadratic dependence on $\mathrm{N}_{2} \mathrm{O}$ abundance). In the absence of detailed information on the experimental conditions hinders better estimates of this interference. We do note that the experiments of Biermann et al. were the state of the art about 40 years ago and they did their best to obtain the rate coefficient for a slow reaction.

Very recently, the theoretical calculations of Nguyen et al. placed an upper limit for the rate coefficient for $\mathrm{OH}$ reaction with $\mathrm{N}_{2} \mathrm{O}$ to be $\left(<7 \times 10^{-28} \mathrm{~cm}^{3}\right.$ molecule $\left.\mathrm{e}^{-1} \mathrm{~s}^{-1}\right)$. 
Our measured upper limit is much larger than that calculated by Nguyen et al. but, being an upper limit, it is consistent with their estimates.

\subsection{Reaction of $\mathrm{NO}_{3}$ with $\mathrm{N}_{2} \mathrm{O}$}

Fig. 2 shows the measured temporal profiles of $\mathrm{NO}_{3}$ and $\mathrm{N}_{2} \mathrm{O}_{5}$ mixing ratios in the chamber in the presence of $\mathrm{N}_{2} \mathrm{O}$ along with the fits of the profiles to a reaction scheme consisting of Reactions 2 through 6 . With the known values of the rate coefficients for Reactions 3 and 4, and the known initial concentrations of $\mathrm{NO}_{3}, \mathrm{~N}_{2} \mathrm{O}_{5}$ and $\mathrm{NO}_{2}$ (the initial concentration of $\mathrm{NO}_{2}$ was derived from $\mathrm{k}_{\mathrm{eq}}$ ), the values of $\mathrm{k}_{5}$ and $\mathrm{k}_{6}$ were derived from the fits to profiles (1) and (2). As noted in our earlier papers, ${ }^{25}$ the fits were carried out by simultaneously minimizing the sum of squares of the residuals for both profiles. Subsequent to the addition of $\mathrm{N}_{2} \mathrm{O}$ (lower traces 3 and 4), the profiles were again fit to extract $\mathrm{k}_{2}$.

Experiments were carried out with different initial concentrations of $\mathrm{N}_{2} \mathrm{O}$ and two samples of $\mathrm{N}_{2} \mathrm{O}$ ( $99 \%$ and $99.998 \%$ purities). The uncertainty in the obtained values of $\mathrm{k}_{2}$ due to fitting was very small, often much less than $5 \%$. The uncertainty in the precision of our measured rate coefficient were obtained by the standard deviation of the mean of multiple measurements and including the Student $t$ value for the limited number of measurements. The results of our measurements for $\mathrm{N}_{2} \mathrm{O}$ are given in Table 2. 
Table 2. Summary of the experimental conditions and rate coefficients for reaction of $\mathrm{NO}_{3}$ with $\mathrm{N}_{2} \mathrm{O}$ at $(298.0 \pm 1.5) \mathrm{K}$.

\begin{tabular}{|c|c|c|c|c|c|c|}
\hline \multirow[t]{2}{*}{$\mathrm{N}_{2} \mathrm{O}$ purity } & \multicolumn{4}{|c|}{ Initial mixing ratio } & \multirow{2}{*}{$\begin{array}{l}\mathrm{k}_{2}^{\mathrm{a}} \\
10^{-20} \mathrm{~cm}\end{array}$} & \multirow{2}{*}{$\begin{array}{c}\mathrm{k}_{2}{ }^{\mathrm{b}} \\
\text { incl. systematic } \\
\text { errors } \\
{ }^{3} \text { molecule }^{-1} \mathrm{~s}^{-1}\end{array}$} \\
\hline & $\begin{array}{c}\mathrm{N}_{2} \mathrm{O} \\
(\mathrm{ppmv})\end{array}$ & $\begin{array}{c}\mathrm{NO}_{3} \\
\text { (ppbv) }\end{array}$ & $\begin{array}{c}\mathrm{N}_{2} \mathrm{O}_{5} \\
(\mathrm{ppbv})\end{array}$ & $\begin{array}{c}\mathrm{NO}_{2} \\
\text { (ppbv) }\end{array}$ & & \\
\hline \multirow{6}{*}{$99 \%$} & 867 & 0.38 & 6.75 & 21.76 & 5.00 & \\
\hline & 819 & 0.52 & 10.47 & 25.17 & 5.50 & \\
\hline & 2148 & 0.39 & 6.81 & 22.27 & 2.12 & \\
\hline & 2040 & 0.59 & 11.55 & 25.08 & 1.70 & \\
\hline & 2707 & 0.39 & 7.46 & 21.96 & 1.08 & \\
\hline & 2439 & 0.39 & 8.05 & 24.02 & 1.10 & \\
\hline \multirow{7}{*}{$99.998 \%$} & \multicolumn{5}{|c|}{ Average $2.75 \pm 2.08$} & \multirow[t]{6}{*}{$2.75 \pm 2.20$} \\
\hline & 2277 & 0.11 & 3.24 & 18.62 & 2.62 & \\
\hline & 2214 & 0.49 & 14.84 & 19.83 & 1.01 & \\
\hline & 3201 & 0.12 & 4.04 & 22.64 & 3.78 & \\
\hline & 2386 & 0.17 & 4.54 & 18.21 & 3.45 & \\
\hline & 2320 & 0.34 & 9.85 & 19.55 & 2.97 & \\
\hline & \multicolumn{5}{|c|}{ Average $2.77 \pm 1.34$} & $2.77 \pm 1.52$ \\
\hline
\end{tabular}

${ }^{\mathrm{a}}$ The $\mathrm{k}_{2}$ values shown were derived by simultaneously fitting the observed profiles of $\mathrm{NO}_{3}$ and $\mathrm{N}_{2} \mathrm{O}_{5}$ to a least squares algorithm. The quoted errors are at the $95 \%$ confidence level and indicate the precision of our measurements. It also accounts for limited number of measurements by using the Student $\mathrm{t}$ distribution contribution.

b The quoted errors include estimated systematic errors as described in the text.

The errors in $\mathrm{k}_{2}$ from: (1) the precision in the measurements of $\mathrm{NO}_{3}, \mathrm{~N}_{2} \mathrm{O}_{5}$ and $\mathrm{N}_{2} \mathrm{O}$; (2) the uncertainty of the rate coefficients used in the reaction schemes used in the fitting; (3) the precision of curve fitting; and (4) the presence of reactive impurities in the sample of the reactants. 
In the present study, the systematic errors in measurements of $\mathrm{NO}_{3}$ and $\mathrm{N}_{2} \mathrm{O}_{5}$ using the CRDS system employed here have been assessed to be $-8 /+11 \%$ for $\mathrm{NO}_{3}$ and $-9 /+12 \%$ for $\mathrm{N}_{2} \mathrm{O}_{5}$, as noted earlier. Systematic errors in the measured concentration of the $\mathrm{N}_{2} \mathrm{O}$ are estimated by using the uncertainty of the slope in the calibration plot $(<$ $1 \%)$ and the uncertainty in measuring reactants concentration for the calibration (5\%), both at the $95 \%$ confidence level. We simply added these two errors together to get the estimated uncertainty in the concentration of $\mathrm{N}_{2} \mathrm{O}$ in the chamber since they could be correlated. The overall estimated error was calculated by adding in quadrature the fitting error, estimated contribution of absolute concentrations of $\mathrm{NO}_{3}$ and $\mathrm{N}_{2} \mathrm{O}_{5}$, the precision of $\mathrm{k}_{2}$ from the fitting routine, and the estimated uncertainty in the concentration of the $\mathrm{N}_{2} \mathrm{O}$. The uncertainty in the fitting, as noted above, is better than $5 \%$. The uncertainty of the rate coefficients used in the reaction scheme is around $10 \%{ }^{11}$ Table 2 lists the uncertainties in the measured values of $\mathrm{k}_{2}$ along with the estimated systematic errors.

Another potential source of error in the measured value of $k_{2}$ is the presence of reactive impurities in the samples of $\mathrm{N}_{2} \mathrm{O}$. Two cylinders of $\mathrm{N}_{2} \mathrm{O}$ with different stated purities (99\% and 99.998\%) were used. The derived rate coefficients for these two sources of $\mathrm{N}_{2} \mathrm{O}$ are similar (Table 2) since the main impurities are unreactive chemicals such as, $\mathrm{N}_{2}, \mathrm{O}_{2}$, and $\mathrm{CO}_{2}$. We do not believe that our reported values were greatly affected by the presence of reactive impurities. Yet, our reported values should be treated as the upper limits of $\mathrm{k}_{2}$ since it is a very slow reaction and we recommend $\mathrm{k}_{2} \leq$ $5 \times 10^{-20} \mathrm{~cm}^{3}$ molecule $\mathrm{s}^{-1}$ at $\mathrm{T}=(298.0 \pm 1.5) \mathrm{K}$ and $(1000 \pm 5)$ hpa of air. 
Comparison with literature values: This reaction has been subject to only one previous investigation. Cantrell et al. ${ }^{18}$ studied this reaction in a 450L Pyrex cell at room temperature. They did not observe loss of $\mathrm{N}_{2} \mathrm{O}$ through $\mathrm{NO}_{3}$ reaction and reported an upper limit of $2 \times 10^{-17} \mathrm{~cm}^{3}$ molecule $\mathrm{e}^{-1} \mathrm{~s}^{-1}$. The upper limit of $\mathrm{k}_{2}$ we obtained is about two orders of magnitude smaller.

\subsection{Calculated reaction pathways and barrier}

The potential energy surface for the reaction of $\mathrm{N}_{2} \mathrm{O}$ with $\mathrm{OH}$ and $\mathrm{NO}_{3}$ radicals were calculated as a part of this study. However, since those calculations, the energetics and reaction paths have been calculated and reported by Nguyen et al. ${ }^{17,} 19$ Therefore, we have just shown the calculated potential energy surfaces in the Supplementary Information.

\section{Atmospheric significance of measured rate coefficients}

Our results show that the reactions of $\mathrm{OH}$ and $\mathrm{NO}_{3}$ with $\mathrm{N}_{2} \mathrm{O}$ are very slow. Using the upper limit for $\mathrm{k}_{1}$ reported here, we estimate that the atmospheric lifetime of $\mathrm{N}_{2} \mathrm{O}$ is reduced by at most $4 \%$ to 116 yr., from the currently used 120 yr. (This calculation assumes that the globally and diurnally average tropospheric $\mathrm{OH}$ abundance is $1 \times 10^{6}$ $\mathrm{cm}^{-3}$ ). Theoretical calculations of $\mathrm{k}_{1}$ by Nguyen et al. suggests that the influence of the $\mathrm{OH}$ reaction with $\mathrm{N}_{2} \mathrm{O}$ is negligibly small in the atmosphere. Our upper limit for $\mathrm{k}_{2}$ suggests that the contribution of Reaction (2) negligible. Even if we assume a globally average $\mathrm{NO}_{3}$ concentration of $1 \times 10^{7} \mathrm{~cm}^{-3}$, a quantity that remains undefined to date, the contribution of this reaction would be at most $0.2 \%$ to the calculated $\mathrm{N}_{2} \mathrm{O}$ lifetime. Therefore, we suggest that Reactions (1) and (2) do not contribute to the calculated 
lifetime of $\mathrm{N}_{2} \mathrm{O}$. It is interesting to note that the tropospheric loss of $\mathrm{N}_{2} \mathrm{O}$ via its reaction with $\mathrm{O}\left({ }^{1} \mathrm{D}\right)$, present at very small concentration of $<0.1 \mathrm{~cm}^{-3}$, would contribute more to $\mathrm{N}_{2} \mathrm{O}$ loss than either $\mathrm{OH}$ or $\mathrm{N}_{2} \mathrm{O}$ reactions!

Acknowledgment: This work was carried out at CNRS in Orléans, France. It was supported by Labex Voltaire (ANR-10-LABX-100-01), the European Union's Horizon 2020 research and innovation programme through the EUROCHAMP-2020 Infrastructure Activity under grant agreement No. 730997, and ARD PIVOTS program (supported by the Centre-Val de Loire regional council). Europe invests in Centre-Val de Loire with the European Regional Development Fund. ARR acknowledges the Le Studium Advanced Institute of Loire Valley for a Research Professorship. 


\section{References}

1. G. Myhre, D. Shindell, F.-M. Bréon, W. Collins, J. Fuglestvedt, J. Huang, D. Koch, J.F. Lamarque, D. Lee, B. Mendoza, T. Nakajima, A. Robock, G. Stephens, T. Takemura and H. Zhang,Anthropogenic and Natural Radiative Forcing. In: Climate Change, The Physical Science Basis. Contribution of Working Group I to the Fifth Assessment Report of the Intergovernmental Panel on Climate Change, 2013.

2. A. R. Ravishankara, J. S. Daniel and R. W. Portmann,Nitrous Oxide $\left(\mathrm{N}_{2} \mathrm{O}\right)$ : The Dominant Ozone-Depleting Substance Emitted in the 21st Century, Science, 2009, 326, 123-125.

3. UNEP, Drawing Down $\mathrm{N}_{2} \mathrm{O}$ to Protect Climate and the Ozone Layer. A UNEP Synthesis Report., United Nations Environment Programme (UNEP), Nairobi, Kenya, 2013.

4. P. N. M. Ko, S. Reimann, S. Strahan,SPARC Report on the Lifetimes of Stratospheric Ozone-Depleting Substances, Their Replacements, and Related Species, SPARC Report No. 6, WCRP-15, 2013.

5. A. Lesar, M. Hodošček and M. Senegačnik, Experimental and theoretical studies of the decomposition of $\mathrm{N}_{2} \mathrm{O}$ catalyzed by chlorine, J. Chem. Phys., 1996, $\mathbf{1 0 5}, 917-926$.

6. A. Lesar and M. Hodoscek, Transition State Structure and Energetics of the $\mathrm{N}_{2} \mathrm{O}+\mathrm{X}(\mathrm{X}=\mathrm{Cl}, \mathrm{Br})$ Reactions, J. Chem. Inf. Comput. Sci., 2002, 42, 706-711. 
7. A. Lesar and M. Senegačnik, ${ }^{15} \mathrm{~N}$ and ${ }^{18} \mathrm{O}$ kinetic isotope effects in the thermal decomposition of $\mathrm{N}_{2} \mathrm{O}$ catalyzed by bromine, J. Chem. Phys., 1993, 99, 187-195.

8. A. Lesar and M. Hodošček, Ab initio molecular orbital and density functional characterization of the potential energy surface of the $\mathrm{N}_{2} \mathrm{O}+\mathrm{Br}$ reaction, J. Chem. Phys., 1998, 109, 9410-9416.

9. X. Wang, D. J. Jacob, S. D. Eastham, M. P. Sulprizio, L. Zhu, Q. Chen, B. Alexander, T. Sherwen, M. J. Evans, B. H. Lee, J. D. Haskins, F. D. Lopez-Hilfiker, J. A. Thornton, G. L. Huey and H. Liao, The role of chlorine in global tropospheric chemistry, Atmos. Chem. Phys., 2019, 19, 3981-4003.

10. W. R. Simpson, S. S. Brown, A. Saiz-Lopez, J. A. Thornton and R. von Glasow, Tropospheric Halogen Chemistry: Sources, Cycling, and Impacts, Chem Rev., 2015, 115, 4035-4062.

11. S. P. Sander. J. B. Burkholder, J. P. D. Abbatt,J. R. Barker,R. E. Huie,C. E. Kolb,M. J. Kurylo,V. L. Orkin,D. M. Wilmouth,P. H. Wine,Chemical Kinetics and Photochemical Data for Use in Atmospheric Studies, 2015.

12. J. S. Chang and F. Kaufman,Upper limits of the rate constants for the reactions of $\mathrm{CFCl}_{3}(\mathrm{~F}-11), \mathrm{CF}_{2} \mathrm{Cl}_{2}(\mathrm{~F}-12)$, and $\mathrm{N}_{2} \mathrm{O}$ with $\mathrm{OH}$. Estimates of corresponding lower limits to their tropospheric lifetimes, Geophys. Res. Lett., 1977, 4, 192-194. 
13. R. Atkinson, R. A. Perry and J. N. Pitts, Kinetics of the reactions of $\mathrm{OH}$ radicals with $\mathrm{CO}$ and $\mathrm{N}_{2} \mathrm{O}$, Chem. Phys. Lett., 1976, 44, 204-208.

14. S. Gordon and W. A. Mulac, Reaction of the $O H(X /$ sup $2 / I I)$ radical produced by the pulse radiolysis of water vapor, ; Argonne National Lab., IL, 1975.

15. H. W. Biermann, C. Zetzsch and F. Stuhl,Rate Constant for the Reaction of $\mathrm{OH}$ with $\mathrm{N}_{2} \mathrm{O}$ at $298 \mathrm{~K}$, Berichte der Bunsengesellschaft für physikalische Chemie, 1976, 80, 909-911.

16. E. L. Fleming, C. George, D. E. Heard, C. H. Jackman, M. J. Kurylo, W. Mellouki, V. L. Orkin, W. H. Swartz, T. J. Wallington, P. H. Wine and J. B. Burkholder, The impact of current $\mathrm{CH}_{4}$ and $\mathrm{N}_{2} \mathrm{O}$ atmospheric loss process uncertainties on calculated ozone abundances and trends, $J$. Geophys. Res.: Atmos., 2015, 120, 5267-5293.

17. T. L. Nguyen, A. R. Ravishankara and J. F. Stanton,Analysis of the potential atmospheric impact of the reaction of $\mathrm{N}_{2} \mathrm{O}$ with $\mathrm{OH}$, Chem. Phys. Lett., 2018, 708, 100-105.

18. C. A. Cantrell, J. A. Davidson, R. E. Shetter, B. A. Anderson and J. G. Calvert,Reactions of nitrate radical and nitrogen oxide $\left(\mathrm{N}_{2} \mathrm{O}_{5}\right)$ with molecular species of possible atmospheric interest, J. Phys. Chem., 1987, 91, 6017-6021. 
19. T. L. Nguyen, M. N. Romanias, A. R. Ravishankara, A. M. Zaras, P. Dagaut and J. F. Stanton, The atmospheric impact of the reaction of $\mathrm{N}_{2} \mathrm{O}$ with $\mathrm{NO}_{3}$ : A theoretical study, Chem. Phys. Lett., 2019, 731, 136605.

20. F. Bernard, G. Eyglunent, V. Daele and A. Mellouki,Kinetics and Products of Gas-Phase Reactions of Ozone with Methyl Methacrylate, Methyl Acrylate, and Ethyl Acrylate, J. Phys. Chem. A, 2010, 114, 83768383.

21. H. Chen, Y. Ren, M. Cazaunau, V. Dalele, Y. Hu, J. Chen and A. Mellouki,Rate coefficients for the reaction of ozone with 2-and 3-carene, Chem. Phys. Lett., 2015, 621, 71-77.

22. G. L. Vaghjiani and A. R. Ravishankara,New measurement of the rate coefficient for the reaction of $\mathrm{OH}$ with methane, Nature, 1991, 350, 406409.

23. A. Mellouki, S. Teton, G. Laverdet, A. Quilgars and G. Le Bras, Kinetic studies of $\mathrm{OH}$ reactions with $\mathrm{H}_{2} \mathrm{O}_{2}, \mathrm{C}_{3} \mathrm{H}_{8}$ and $\mathrm{CH}_{4}$ using the pulsed laser photolysis - laser induced fluorescence method, Journal de chimie physique, 1994, 91, 473-487.

24. L. Zhou, A. R. Ravishankara, S. S. Brown, M. Idir, K. J. Zarzana, V. Daële and A. Mellouki,Kinetics of the Reactions of $\mathrm{NO}_{3}$ Radical with Methacrylate Esters, J. Phys. Chem. A, 2017, 121, 4464-4474. 
25. L. Zhou, A. R. Ravishankara, S. S. Brown, K. J. Zarzana, M. Idir, V. Daële and $\mathrm{A}$. Mellouki,Kinetics of the reactions of $\mathrm{NO}_{3}$ radical with alkanes, Phys. Chem. Chem. Phys., 2019, 21, 4246-4257.

26. H. Fuchs, W. P. Dube, S. J. Cicioira and S. S. Brown,Determination of inlet transmission and conversion efficiencies for in situ measurements of the nocturnal nitrogen oxides, $\mathrm{NO}_{3}, \mathrm{~N}_{2} \mathrm{O}_{5}$ and $\mathrm{NO}_{2}$, via pulsed cavity ringdown spectroscopy, Anal. Chem., 2008, 80, 6010-6017.

27. W. P. Dube, S. S. Brown, H. D. Osthoff, M. R. Nunley, S. J. Ciciora, M. W. Paris, R. J. McLaughlin and A. R. Ravishankara,Aircraft instrument for simultaneous, in situ measurement of $\mathrm{NO}_{3}$ and $\mathrm{N}_{2} \mathrm{O}_{5}$ via pulsed cavity ring-down spectroscopy, Rev. Sci. Instrum., 2006, 77.

28. H. Fuchs, W. R. Simpson, R. L. Apodaca, T. Brauers, R. C. Cohen, J. N. Crowley, H. P. Dorn, W. P. Dubé, J. L. Fry, R. Häseler, Y. Kajii, A. Kiendler-Scharr, I. Labazan, J. Matsumoto, T. F. Mentel, Y. Nakashima, F. Rohrer, A. W. Rollins, G. Schuster, R. Tillmann, A. Wahner, P. J. Wooldridge and S. S. Brown,Comparison of $\mathrm{N}_{2} \mathrm{O}_{5}$ mixing ratios during NO3Comp 2007 in SAPHIR, Atmos. Meas. Tech., 2012, 5, 2763-2777.

29. J. A. Davidson, A. A. Viggiano, C. J. Howard, I. Dotan, F. C. Fehsenfeld, D. L. Albritton and E. E. Ferguson,Rate constants for reactions of $\mathrm{O}_{2}{ }^{+}$, $\mathrm{NO}_{2}{ }^{+}, \mathrm{NO}^{+}, \mathrm{H}_{3} \mathrm{O}^{+}, \mathrm{CO}_{3}{ }^{-}, \mathrm{NO}_{2}^{-}$, and halide ions with $\mathrm{N}_{2} \mathrm{O}_{5}$ at $300 \mathrm{~K}, J$. Chem. Phys., 1978, 68, 2085-2087. 
30. R. Atkinson, D. L. Baulch, R. A. Cox, J. N. Crowley, R. F. Hampson, R. G. Hynes, M. E. Jenkin, M. J. Rossi, J. Troe and I. Subcommittee,Evaluated kinetic and photochemical data for atmospheric chemistry: Volume II- gas phase reactions of organic species, Atmos. Chem. Phys., 2006, 6, 3625-4055.

31. G. L. Vaghjiani and A. R. Ravishankara, Photodissociation of $\mathrm{H}_{2} \mathrm{O}_{2}$ and $\mathrm{CH}_{3} \mathrm{OOH}$ at $248 \mathrm{~nm}$ and $298 \mathrm{~K}$ : Quantum yields for $\mathrm{OH}, \mathrm{O}\left({ }^{3} \mathrm{P}\right)$ and $\mathrm{H}\left({ }^{2} \mathrm{~S}\right), J$. Chem. Phys., 1990, 92, 996-1003. 
Figures:

Figure 1

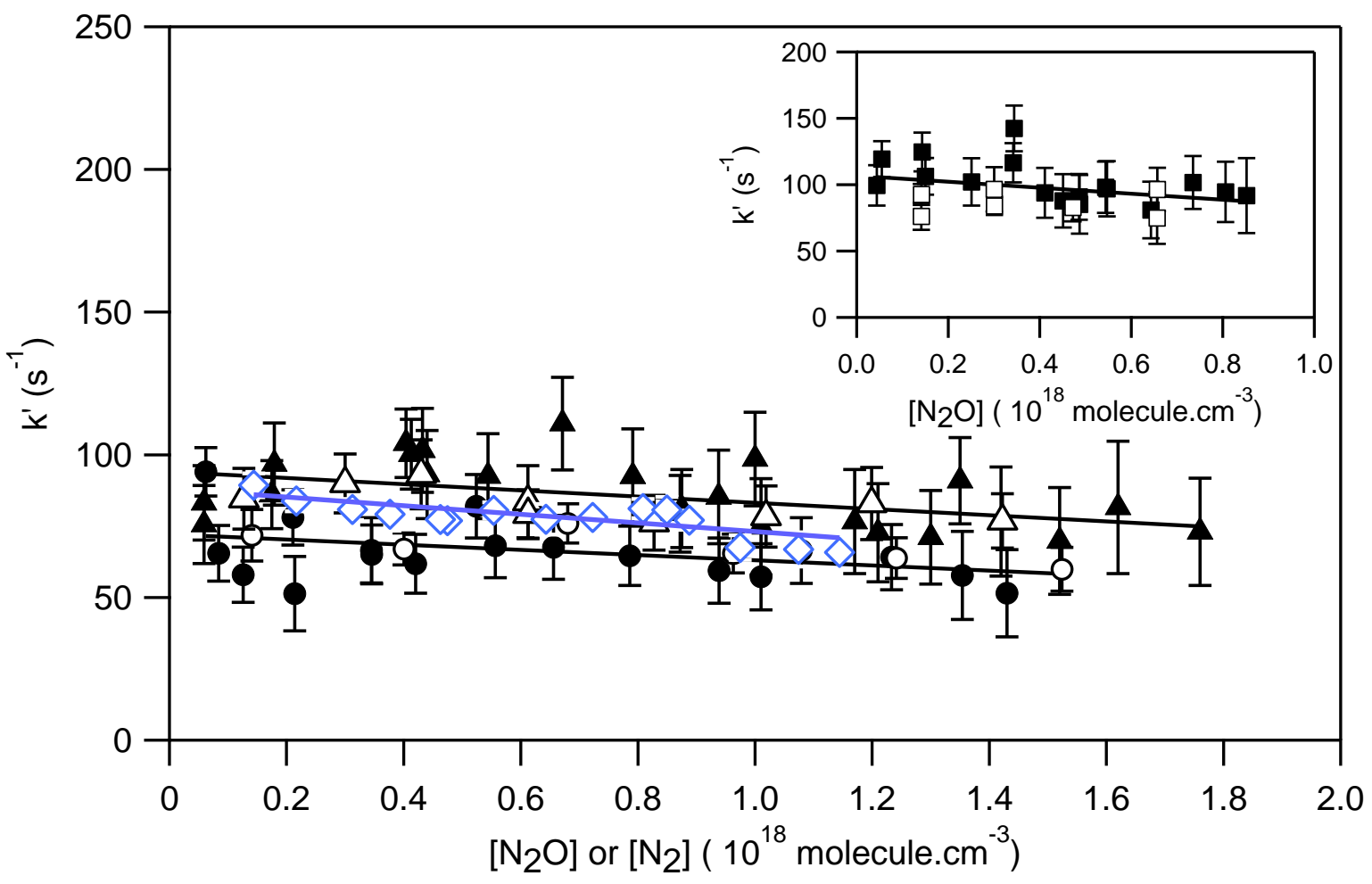

Fig. 1. Pseudo-first order rate coefficients for the loss of $\mathrm{OH}$ radicals (k') plotted against the $\mathrm{N}_{2} \mathrm{O}$ and

$\mathrm{N}_{2}$ concentrations. The lines represent the linear least-squares fits of data and the slope yields the bimolecular rate coefficient $\mathrm{k}_{1}$. The filled symbols were obtained in $99 \%$ pure $\mathrm{N}_{2} \mathrm{O}$ while the open symbols were from $99.998 \%$ pure $\mathrm{N}_{2} \mathrm{O}$ at $372 \mathrm{~K} \quad(\boldsymbol{\square}$ and $\square), 298 \mathrm{~K}(\boldsymbol{\Delta}$ and $\triangle$ ), and $253 \mathrm{~K}(\bullet$ and $\circ)$. The obtained values of $\mathrm{k}_{1}$ at 372,298 , and $253 \mathrm{~K}$ are, respectively, $\quad(-2.26 \pm 1.34) \times 10^{-17},(-1.09 \pm$ $0.34) \times 10^{-17}$ and $(-9.06 \pm 3.91) \times 10^{-18} \mathrm{~cm}^{3}$ molecule $\mathrm{e}^{-1} \mathrm{~s}^{-1}$. The open diamond $(\diamond)$ represents 298 $\mathrm{K}$ data for the addition of $\mathrm{N}_{2}$, which yields a slope of $(-1.51 \pm 0.38) \times 10^{-17} \mathrm{~cm}^{3} \cdot$ molecule $^{-1} \cdot \mathrm{s}^{-1}$. The error bars are the $2 \sigma$ uncertainties from the fits to the individual $\mathrm{OH}$ decays plus the estimated systematic error $5 \%$ due to uncertainties in measured concentrations of $\mathrm{N}_{2} \mathrm{O}$ and $\mathrm{N}_{2}$. 
Figure 2

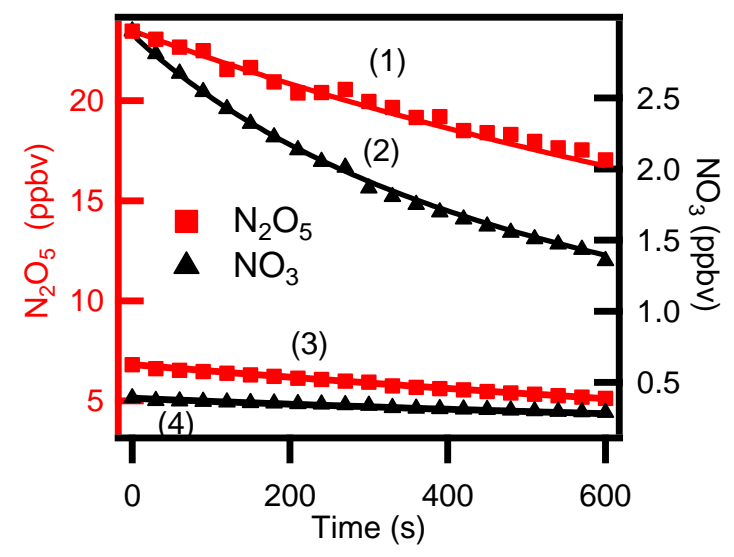

Fig. 2. Observed $\mathrm{NO}_{3}$ and $\mathrm{N}_{2} \mathrm{O}_{5}$ mixing ratios (black triangles $\boldsymbol{\Lambda}$ and red squares $\boldsymbol{\square}$ ) and their simulated temporal profiles (lines) before (profiles 1 and 2) and after (profiles 3 and 4) the injection of $\mathrm{N}_{2} \mathrm{O}$ into the chamber where $\mathrm{NO}_{3}$ and $\mathrm{N}_{2} \mathrm{O}_{5}$ were present at equilibrium. The concentration of $\mathrm{N}_{2} \mathrm{O}$ was $5.28 \times 10^{13}$ molecule $\mathrm{cm}^{-3}$. The fits yield a value of $\mathrm{k}_{2}=2.30 \times 10^{-20} \mathrm{~cm}^{3}$ molecule $\mathrm{s}^{-1} \mathrm{~s}^{-1}$. Note that it took a long time ( $\sim 30$ mins) to inject sufficient $\mathrm{N}_{2} \mathrm{O}$ into the chamber. During this time $\mathrm{NO}_{3}$ and $\mathrm{N}_{2} \mathrm{O}_{5}$ decayed further; however, the signal to noise ratio for the detected species were excellent. 